\title{
Consumption of working time in strawberry production
}

\author{
MARITTA YLÄRANTA AND VILJO RYYNÄNEN \\ Department of Agricultural Economics, University of Helsinki, SF-00710 Helsinki 71.
}

Abstract. The results of an empirical study of the working time consumed in strawberry production on Finnish farms are reviewed. Forty growers participated in the study, which took place between 1977-80. The purpose of the study was to determine how much time was consumed in working the fallow ground and during the summer of planting, in the first fruiting year and in the next four or five growth periods. Two cultivation methods were treated separately. The whole strawberry cultivation area was 95,1 ha.

In the method in which the earth surrounding the bushes was covered with a black plastic film, the total consumption of working time was $409,0 \mathrm{~h} / \mathrm{ha}$ using a one-row system and $572,5 \mathrm{~h} / \mathrm{ha}$ using a double-row system during the fallow period and the summer of planting. During the first fruiting year the figure was 492,5 $\mathrm{h} / \mathrm{ha}$ and in the next fruiting years $1348,5 \mathrm{~h} / \mathrm{ha}$, including the time spent on harvesting. Where mulch was applied, the corresponding averages were $235,5 \mathrm{~h} / \mathrm{ha}, 612,5 \mathrm{~h} / \mathrm{ha} 1182,0 \mathrm{~h} / \mathrm{ha}$.

Factors affecting the variation in the total working time between farms were studied by linear regression analysis. Factors such as e.g. total strawberry cultivation area, the number of plants per hectare and the number of the years the grower had been cultivating strawberries, did not explain the variation in the working time satisfactorily. The yield per hectare, percentage of the different varieties cultivated, planting system, cultivation and picking methods explained only $33 \%$ of the variation in labour output of picking.

\section{Introduction}

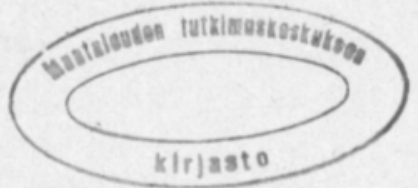

The purpose of the study made in $1977-80$ was to examine the working time consumed in strawberry production. There are two main cultivation methods. In the first the ridges are covered with a black plastic film, and in the second mulch is applied. The labour consumption was studied in both these methods and in cultivations of different ages.

Besides establishing standards for the different tasks involved, an attempt was made to study factors affecting the variation in working time from farm to farm.

The results are presented so that they can be used e.g. in education and in an advisory capacity where economic data is needed for farm planning. They could also serve as a kind of guideline for strawberry growers in planning labour organisation on their farms. In addition, the results are useful to the authorities in evaluating e.g. damage to strawberry cultivation. 
Of a total of 40 growers participating in the study, the number taking part per year varied from 8 to 26 . Correspondingly, the total strawberry cultivation area was 95,1 ha, while the area studied in an individual year varied from 13,4 ha to 40,8 ha. The farms were situated in south, southwest, southeast and central Finland. The average area of strawberry cultivation was 1,6 ha per farm. On average, strawberries covered about $20 \%$ of the total field area of the farms. 103 calculations were made of the working time consumed on the farms. $53,5 \%$ of the farms used a black plastic film to cover the ridges, while the remaining $46,5 \%$ applied mulch. Senga Sengana was the most common variety cultivated, Zefyr and Red Gautlet were also used though to a lesser extent.

Each day the growers recorded data on the work done to an accuracy of half an hour. Forms were provided for this purpose. The forms were returned to the university at intervals of $2-4$ weeks.

The information supplied by the growers specified the number of working hours consumed per hectare. The labour standards established represent the mean values in the observations. The distribution of labour during the growth period was illustrated by column diagrams. The reasons underlying the variation in working time from farm to farm were studied by linear regression analysis.

\section{Total working time and its distribution}

\section{1) The fallow period and summer of planting}

The time consumed by work done while the ground lay fallow, and during the summer when planting took place, is broken down in Table 1 according to the various tasks and cultivation methods involved. Ground preparation includes everything done before the actual planting. If the planting was done in the spring, this work took place during the preceding summer. With autumn planting, it was done earlier in the summer. Harrowing and spraying with herbicides were carried out several times.

With the black plastic-covered ridges, fertilizing took $1,5 \mathrm{~h} / \mathrm{ha}$ more time than with mulching. In the former case, greater quantities of fertilizer were used. The fertilizing might be e.g.: garden compound fertilizer with trace-elements (6-1621) $900 \mathrm{~kg} / \mathrm{ha}$, superphosphate $500 \mathrm{~kg} / \mathrm{ha}$ and potassium sulphate $500 \mathrm{~kg} / \mathrm{ha}$. With mulching, it was e.g.: garden compound fertilizer $700 \mathrm{~kg} / \mathrm{ha}$, superphosphate $400 \mathrm{~kg} / \mathrm{ha}$ and potassium sulphate $400 \mathrm{~kg} / \mathrm{ha}$.

Besides the actual planting, planting includes preparatory work such as transferring plants from the propagation sites to the field. Taking into account all the tasks involved in planting, the labour output in hand planting is on average 89 plants per man hour. In machine planting, the average is 197 plants per man hour.

The black plastic film was spread by a tractor-drawn machine forming tight ridges and covering them with plastic film at the same time. 
Table 1. The consumption of working time $(\mathrm{h} / \mathrm{ha})$ in strawberry cultivation during the fallow period and the summer of planting.

\begin{tabular}{|c|c|c|c|c|}
\hline \multirow[t]{2}{*}{ Task } & \multicolumn{2}{|c|}{$\begin{array}{l}\text { Black plastic- } \\
\text { covered ridges }\end{array}$} & \multicolumn{2}{|c|}{ Mulch } \\
\hline & Man & Tractor & Man & Tractor \\
\hline Ground preparation & 43.0 & 36.0 & 41.0 & 34.0 \\
\hline Fertilizing & 7.0 & 3.5 & 5.5 & 3.5 \\
\hline Spreading the plastic film & 36.5 & 16.5 & - & - \\
\hline \multicolumn{5}{|l|}{$\begin{array}{l}\text { Planting } \\
- \text { by hand }\end{array}$} \\
\hline $\begin{array}{l}\text { 1. one-row system } \\
(24000 \text { plants/ha) }\end{array}$ & 251.0 & 3.0 & - & - \\
\hline $\begin{array}{l}\text { 2. double-row system } \\
(34000 \text { plants/ha) }\end{array}$ & 414.5 & 5.0 & - & - \\
\hline $\begin{array}{l}- \text { planting machine } \\
(24000 \text { plants } / \mathrm{ha})\end{array}$ & - & - & 122.0 & 23.5 \\
\hline Irrigation & 17.0 & 14.5 & 20.0 & 9.0 \\
\hline Weed control & 33.5 & 1.5 & 37.5 & 17.5 \\
\hline $\begin{array}{l}\text { (spraying with tractor and } \\
\text { knapsack sprayers, weeding) }\end{array}$ & & & & \\
\hline $\begin{array}{l}\text { Disease and vermin } \\
\text { control (tractor and } \\
\text { back-borne motor sprayers) }\end{array}$ & 6.5 & 2.5 & 1.0 & - \\
\hline General control & 5.0 & - & 2.0 & - \\
\hline Diverse & 9.5 & - & 6.5 & - \\
\hline $\begin{array}{l}\text { Total } \\
\text { 1. Planting by hand }\end{array}$ & & & & \\
\hline $\begin{array}{l}\text { one-row system } \\
\text { 2. Planting by hand }\end{array}$ & 409.0 & 77.5 & - & - \\
\hline double-row system & 572.5 & 79.5 & - & - \\
\hline 3. Machine planting & - & - & 235.5 & 87.5 \\
\hline
\end{tabular}

\section{2) The first fruiting year}

The consumption of working time during the first fruiting year is presented in Table 2. The total time taken for cultivation is $80 \%$ greater with mulching than with the plastic-covered ridges. The organic matter used for mulching was halm, sawdust, cutter chips or bark residues. It was spread by shovel from a tractor trailer. In the table, the item "diverse" includes e.g. frost control, clearing away dead leaves in spring, and replacing dead plants.

The yield per hectare was low in the first year so that the time consumed by picking per hectare was also low. The average labour output in picking was 6,0 $\mathrm{kg}$ /hour with the plastic and $3,7 \mathrm{~kg} /$ hour with mulching.

\section{3) The fruiting years}

The consumption of working time in the cultivation of fullgrown strawberries is presented in Table 3. The total time consumed in cultivation is $1,1-1,2$ times greater using plastic-covered ridges than with mulching. Weed control accounts for $32-49 \%$ of the total labour. This is so because as a rule only the paths between the rows of plants can be treated with sprays. The weeds growing in the holes where the plants grow in the plastic film or in plant rows have to be pulled out by hand. 
Table 2. The consumption of working time $(\mathrm{h} / \mathrm{ha})$ and the yield $(\mathrm{kg} / \mathrm{ha})$ in strawberry cultivation during the first fruiting year.

\begin{tabular}{|c|c|c|c|c|}
\hline \multirow[t]{2}{*}{ Task } & \multicolumn{2}{|c|}{$\begin{array}{l}\text { Black plastic- } \\
\text { covered ridges }\end{array}$} & \multicolumn{2}{|c|}{ Mulch } \\
\hline & Man & Tractor & Man & Tractor \\
\hline \multicolumn{5}{|l|}{ 1. Cultivation $(\mathrm{h} / \mathrm{ha})$} \\
\hline \multicolumn{5}{|l|}{ Fertilizing } \\
\hline - by hand & 4.0 & - & - & - \\
\hline - by spreader & - & - & 3.5 & 3.0 \\
\hline Irrigation & 15.5 & 9.0 & 28.0 & 11.0 \\
\hline Mulching & - & - & 80.5 & 26.5 \\
\hline Disease and vermin & 23.5 & 7.0 & 18.0 & 14.0 \\
\hline \multirow{2}{*}{\multicolumn{5}{|c|}{$\begin{array}{l}\text { control (tractor and } \\
\text { back-borne motor sprayers) }\end{array}$}} \\
\hline & & & & \\
\hline Weed control & 107.0 & 3.5 & 153.0 & 3.0 \\
\hline \multirow{2}{*}{\multicolumn{5}{|c|}{$\begin{array}{l}\text { (tractor and knapsack } \\
\text { sprayers, and weeding) }\end{array}$}} \\
\hline & & & & \\
\hline General control & 10.0 & - & 17.0 & - \\
\hline Diverse & 28.5 & - & 38.5 & - \\
\hline Total (cultivation) & 188.5 & 19.5 & 338.5 & 57.5 \\
\hline \multicolumn{5}{|l|}{ 2. Harvesting $(\mathrm{h} / \mathrm{ha})$} \\
\hline Picking & 285.0 & - & 267.0 & - \\
\hline Diverse & 19.0 & - & 7.0 & - \\
\hline Total (harvesting) & 304.0 & - & 274.0 & - \\
\hline Yield (kg/ha) & 1700 & - & 1000 & - \\
\hline
\end{tabular}

Table 3. The consumption of working time $(\mathrm{h} / \mathrm{ha})$ the yield $(\mathrm{kg} / \mathrm{ha})$ in strawberry cultivation during fruiting years.

\begin{tabular}{|c|c|c|c|c|}
\hline \multirow[t]{2}{*}{ Task } & \multicolumn{2}{|c|}{$\begin{array}{l}\text { Black plastic- } \\
\text { covered ridges }\end{array}$} & \multicolumn{2}{|c|}{ Mulch } \\
\hline & Man & Tractor & Man & Tractor \\
\hline \multicolumn{5}{|l|}{ 1. Cultivation $(\mathrm{h} / \mathrm{ha})$} \\
\hline \multicolumn{5}{|l|}{ Fertilizing } \\
\hline A. by hand & 10.0 & - & 10.5 & - \\
\hline B. by spreader & 5.5 & 4.0 & 3.5 & 3.0 \\
\hline Irrigation & 17.0 & 12.0 & 21.0 & 5.5 \\
\hline Mulching & - & - & 24.0 & 12.0 \\
\hline \multicolumn{5}{|l|}{ Disease and vermin control } \\
\hline A. by back-borne motor sprayer & 48.5 & - & 58.0 & - \\
\hline \multicolumn{5}{|l|}{ B. by tractor and back-borne } \\
\hline motor sprayers & 25.0 & 18.5 & 16.5 & 15.0 \\
\hline Weed control & 99.0 & 4.0 & 68.0 & 7.0 \\
\hline \multirow{2}{*}{\multicolumn{5}{|c|}{$\begin{array}{l}\text { (tractor and knapsack } \\
\text { sprayers, and weeding) }\end{array}$}} \\
\hline & & & & \\
\hline General control & 9.5 & - & 5.0 & - \\
\hline Diverse & 45.5 & 3.0 & 27.5 & - \\
\hline \multicolumn{5}{|l|}{ Total (cultivation) } \\
\hline Case A. & 229.5 & 19.0 & 214.0 & 24.5 \\
\hline Case B. & 201.5 & 41.5 & 165.5 & 42.5 \\
\hline \multicolumn{5}{|l|}{ 2. Harvesting $(\mathrm{h} / \mathrm{ha})$} \\
\hline Picking & 1053.0 & - & 943.0 & - \\
\hline Diverse & 80.0 & 15.5 & 49.0 & 4.0 \\
\hline Total (harvesting) & 1133.0 & 15.5 & 992.0 & 4.0 \\
\hline Yield (kg/ha) & 5900 & & 5500 & \\
\hline Picking (h/1 000 kg) & 178 & & 171 & \\
\hline
\end{tabular}


"Diverse" tasks are the same as mentioned in an earlier paragraph. The number of hours varies according to the cultivation method.

Strawberries were harvested by contract pickers. The pickers were 13-18 years old schoolboys and girls, but also other female pickers were used. The average labour output was $5,6 \mathrm{~kg} /$ hour on plots covered with black plastic and $5,8 \mathrm{~kg} / \mathrm{hour}$ on mulched plots. Diverse tasks involved in harvesting were e.g. supervising the work of the pickers, weighing the berries, transporting pickers and berries. These varied greatly from farm to farm.

According to these observations the average yield/ha was $7 \%$ lower with mulching than with the black plastic covering.

Clearing the ground took $89 \mathrm{~h} / \mathrm{ha}$ with the black plastic film and $51 \mathrm{~h} / \mathrm{ha}$ with the mulch. This work included removing the plastic, spraying the plants with herbicide and ploughing the field.

\section{4) The distribution of working time per week}

The distribution of the working time per week is shown in Figure 1. Cases where plastic-covered ridges were used are presented on the left and corresponding cases where mulch was applied, on the right. In the first diagram the column for week 21 represents spreading the plastic film. Planting was done during weeks 2327. Most of the remaining labour went on weed control. With mulching, a planting machine was used. Planting was done in week 31 (right hand diagram above). In the first fruiting year the biggest task in cultivation was weed control. In the right hand diagram (in the middle) cutter chips were spread during weeks 28-29. In fruiting years (diagram below) about $85 \%$ of the total working time was taken up by picking. Weed control ranks as the next time-consuming task.

\section{Discussion}

Studies concerning the consumption of labour in strawberry cultivation have been made in several countries. The study made by KRÅKEVIK (1973), Norway, probably resembles the present study most of all. He reports consumption of the working time in cultivation as being $136 \mathrm{~h} / \mathrm{ha}$ with black plastic-covered ridges and $161 \mathrm{~h} / \mathrm{ha}$ with matted row culture during fruiting years.

The number of hours spent on cultivation is larger in this study. In Table 4 the Finnish results are compared with the Norwegian norms (ANON. 1979).

The Norwegian norms do not differ much from the results of the present study during the fallow period and the summer when planting takes place. In fruiting years, the consumption of working time in cultivation is about $47 \%$ higher in the Finnish results than in the Norwegian norms. This is because the Norwegian norms are based on fields that are free from weeds. The labour involved in harvesting $(\mathrm{h} / \mathrm{ha})$ is almost the same when the crop level is the same. In a German study (RÜGER 1974) the cultivation took up $154 \mathrm{~h} / \mathrm{ha}$ in fruiting years. Plant protection accounted for 28 hours of this, fertilizing for 23 hours and other tasks 103 hours. On the American continent, in southwest Michigan, the consumption of working 

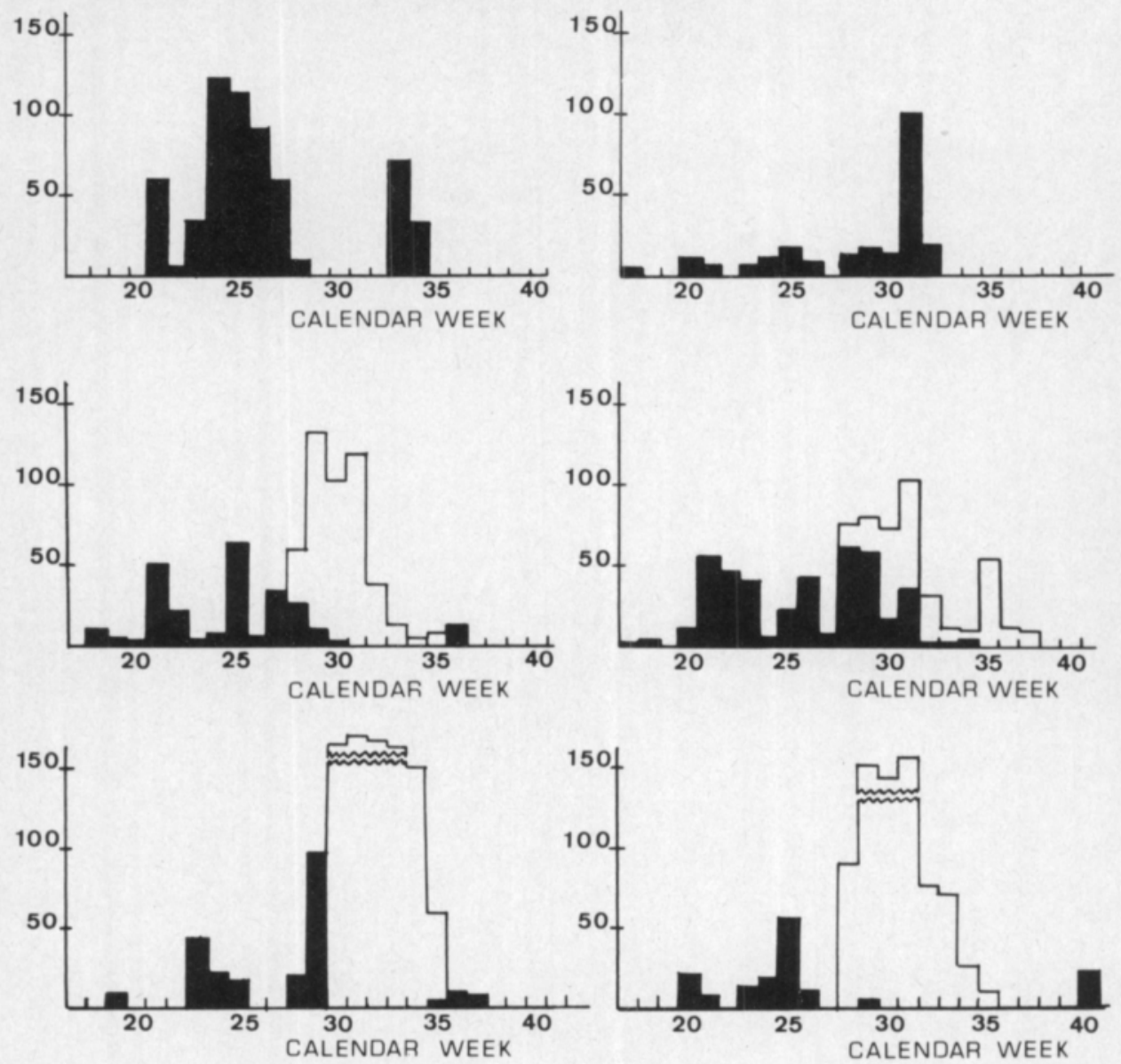

cultivating tasks

HARVESTING TASKS

Fig. 1. The distribution of working time $(\mathrm{h} / \mathrm{ha})$ in strawberry production. The most typical examples of the labour consumed during the summer of planting (above), the first fruiting year (in the middle) and fruiting years (below) are presented. The diagrams on the left show labour consumption with black plastic-covered ridges and those on the right with mulching.

time in the second year of cultivation is 98 hours per hectare (KELSEY and BELTER 1974).

The variation between farms in the consumption of working time was studied by linear regression analysis. The variation was very great in every phase of cultivation but, it was studied only in fruiting years. The difficulty in clarifying the variation lay in the fact that not all the affecting factors could be quantified. Among the determining variables - the total strawberry cultivation area, the area of the field in question, the number of plants per hectare, the age of the grower, the cultivation method, the number of years strawberries had been cultivated - the highest correlation was between the two last mentioned variables $\left(r=0,45^{* * *}\right)$. The variable that seemed to cause the widest variation in the working time was the 
Table 4. The consumption of man hours per hectare and the yield $(\mathrm{kg} / \mathrm{ha})$ in strawberry cultivation according to the Norwegian norms (ANON. 1979) and the Finnish study.

\begin{tabular}{lcccr}
\hline Phase of cultivation & \multicolumn{1}{c}{$\begin{array}{c}\text { Withblack } \\
\text { plastic film } \\
\text { Present } \\
\text { study }\end{array}$} & Norwegian & \multicolumn{2}{c}{$\begin{array}{c}\text { Without black } \\
\text { plastic film } \\
\text { Present } \\
\text { study }\end{array}$ Norwegian } \\
\hline $\begin{array}{l}\text { Period of fallow and summer } \\
\text { of planting }\end{array}$ & 491 & 430 & 236 & 280 \\
$\begin{array}{l}\text { First fruiting year } \\
\text { a) Cultivation }\end{array}$ & 189 & - & 339 & - \\
b) Harvesting & 304 & - & 274 & - \\
$\quad$ Yield (kg/ha) & 1700 & - & 1000 & - \\
$\begin{array}{l}\text { Fruiting years } \\
\text { a) Cultivation }\end{array}$ & 216 & 160 & 190 & 120 \\
b) Harvesting & 1133 & 1150 & 992 & 1150 \\
$\quad$ Yield (kg/ha) & 5900 & 6000 & 5500 & 6000 \\
Clearing the cultivation & 89 & 100 & 51 & - \\
\hline
\end{tabular}

number of years strawberries had been cultivated. In all, the six factors accounted for only $21 \%$ of the variation of the working time consumed in the tasks of cultivation. This shows that the effect of unquantified factors was considerable.

Thirty three per cent of the variation in the picking output $(\mathrm{kg} / \mathrm{h})$ was determined by the method of cultivation, the size of the yield, the planting system (one-row system/double-row system), the percentage of the Senga Sengana-variety and the method of picking. The strongest determining factor was the amount of yield. The bigger the yield, the greater the labour output of picking. KRÅKEVIK (1971) reports that the yield per picking day and the size of berries accounted for $91 \%$ of the variation in picking time in matted row culture. Picking was faster with plastic-covered ridges than with matted row culture. In the present study picking seemed to be faster in rows covered by mulch than in plastic-covered ridges. In this respect the mulching is as good or better than plastic-covered ridges if the plants grow in a single row.

As the problem of time consumption in strawberry cultivation is related particularly to picking, many studies have been made abroad in efforts to reduce the picking time. In an English study minimizing non-productive labour such as walking was emphasized. MOSER (1973) reports on studies made of various wagons that could simplify picking. The labour output could be raised $10-15 \%$ with a tractordrawn wagon compared with conventional picking. Self-moving picking machines have been tested e.g. in the USA. They have a capacity of $0,4 \mathrm{ha} /$ hour, but picking losses are $30-35 \%$. If strawberries are to be harvested mechanically, varieties must be grown in which the berries ripen at the same time and which will tolerate mechanical handling.

Labour for strawberry picking has not been a great problem on Finnish farms as pickers are available. The problem will be the cost of labour for picking, which is increasing steadily. What does also need attention is weed control. This accounts for about $52 \%$ of all the work involved in cultivation in the first fruiting year and, on average, $41 \%$ of all the work involved in cultivation in the fruiting years. This shows that a fallow period of one summer is not enough. 


\section{References}

ANON. 1970. Harvesting strawberries - a work study investigation in Kent. Min. Agric. Fish. and Food. Short Term Leaflet 81.6 p.

- 1979. Handbok for driftsplanlegging 1979/1980. Norges Lantbr. фkon. Inst. 223 p. Oslo.

KELSEY, M. \& BELTER, H. 1974. Economics of strawberry production in southwestern Michigan. Michigan State Univ. Dep.Agric. Econ. Rep. 276. 23 p.

KRÅKEVIK, S. 1971. Arbeidsforbruket med hфsting av baer. A. Jordbaer. Forskn. of fors. i landbr. 22, $3: 287-302$.

- 1973. Arbeidsforbruket i jordbaerproduksjonen. Forskn. og fors. i landbr. 24, 1:33-54.

MOSER, E. 1973. Möglichkeiten zur Senkung der Produktionskosten durch Mechanisches Ernten von Steinund Beerenobst. Acta Hort. 28:95-112.

RÜGER, H. von. 1974. Arbeitsaufwand und Kosten im Erdbeeranbau. Der Erwerbsobstbau 10, 12:184186.

Ms received February 14, 1981

\section{SELOSTUS}

\section{Mansikanviljelyn työnmenekki}

\section{Maritta Yläranta ja Viljo Ryynänen \\ Maatalousekonomian laitos, Helsingin yliopisto, SF-00710 Helsinki 71.}

Vuosina 1977-80 tutkittiin mansikanviljelyn vaatimaa työnmenekkiä yhteensä 40 mansikanviljelyã harjoittavalla maatilalla. Sysäyksenä tutkimuksen aloittamiselle oli kyseisen tiedon puuttuminen kokonaan maastamme ja kyseisen tiedon tarve opetuksessa, neuvonnassa ja erilaisissa arviointitehtävissä. Tutkimuksessa oli mukana yhteensä 95,1 ha:n pinta-ala.

Tyōnmenekki selvitettiin sekã muovikateviljelyssã ettã ns. avomaaviljelyssä, jossa katteena käytettiin olkea, kutterilastua, sahanpurua tai puunkuorijätettä. Tyōnmenekki esitetāän myōs erikseen eri ikäisille kasvustoille.

Perustamisvaiheessa oli kokonaistyönmenekki muovikateviljelyssä yksittäisriviin istutettaessa $409,0 \mathrm{~h} / \mathrm{ha}$ ja paririviin istutettaessa $572,5 \mathrm{~h} / \mathrm{ha}$. Ensimmäisenä satovuonna kokonaistyönmenekki oli $492,5 \mathrm{~h} / \mathrm{ha}$ sekä täysiikäisissä kasvustoissa 1348,5 h/ha sadonkorjuun työnmenekki mukaan lukien. Avomaaviljelyssä perustamisvaiheen työnmenekki oli $235,5 \mathrm{~h} / \mathrm{ha}$, ensimmäisen satovuoden $612,5 \mathrm{~h} / \mathrm{ha}$ ja tãysi-ikäisten kasvustojen 1182,0 h/ha.

Viljelmien välisiä kokonaistyönmenekin vaihteluita pyrittiin selvittämään lineaarisella regressioanalyysillä. Sellaiset tekijät kuin tilan mansikanviljelyn kokonaisala, hehtaarin taimimäärä, mansikanviljelykokemus eivãt selittåneet hoitotyön menekin osalta tilojen välistä vaihtelua tyydyttävästi. Hehtaarisato, lajike, istutusjärjestelmä, viljelymenetelmä ja poimintatapa selvittivät vain $33 \%$ poiminnan tyōtuotoksesta. 